\title{
The Tale of Greenlandite: Commemorating the Two-Hundredth Anniversary of Eudialyte (1819-2019)
}

\author{
Axel S.L. Sjöqvist $(D)$ \\ Department of Earth Sciences, University of Gothenburg, P.O. Box 460, SE-405 30 Göteborg, Sweden; \\ axel.sjoqvist@gvc.gu.se; Tel.: +46-703599245
}

Received: 15 July 2019; Accepted: 16 August 2019; Published: 19 August 2019

\begin{abstract}
Twenty years before the discovery of the mineral eudialyte, a red garnet-like mineral from Greenland was distributed among mineralogists and chemists in Europe. Furthermore, the first chemical analyses of the Greenlandic mineral reported 10 percent by weight of zirconium oxide. It was given the name greenlandite, and after the discovery of eudialyte many have wondered whether greenlandite could actually be eudialyte. Two-hundred years after the original definition of eudialyte I have tried to find out.
\end{abstract}

Keywords: eudialyte; greenlandite; garnet; grenat en masse; schaliger Pyrop

\section{Introduction and Rationale}

The naming and first description of the mineral eudialyte, one of the most iconic zirconosilicate minerals, is attributed to Friedrich Stromeyer (born: 2 August 1776 in Göttingen-died: 18 August 1835 in Göttingen), whose chemical analyses of a few Greenlandic minerals were presented 200 years ago [1,2]. Eudialyte, a red garnet-like mineral, occurs in or closely associated with peralkaline igneous rocks and being rich in sodium, calcium, rare-earth elements, zirconium, and niobium to name only a few, is today appreciated as one of the most complex and diverse mineral substances known. The mineral described by Stromeyer is one out of a few dozen accepted and theoretically possible end-members, and has lent its name to the mineral group. In celebration of the 200-year anniversary of Stromeyer's naming of eudialyte, this text tells a less well-known chapter in the discovery and history of the eudialyte-group minerals.

Stromeyer's eudialyte specimen was acquired by him in a set of Greenlandic minerals from the well-known mineralogist Karl Ludwig Giesecke (born: 6 April 1761 in Augsburg-died: 5 March 1833 in Dublin. Giesecke was born as Johann Georg Metzler, but changed his name after he finished his studies in 1790, when he moved to Vienna to become an actor, poet, and theatre writer [3]. Later in his life, living in Ireland, he was known as Charles Lewis Giesecke), who collected them himself during a longer-than-planned expedition to Greenland from 1806 to 1813. Giesecke's spectacular story is often told and well documented, in particular in the publicised versions of the journal he kept during his time in Greenland [4,5]. I will not retell Giesecke's full story, of which there are excellent biographical accounts already e.g., [3,6,7], but we will revisit how and where Giesecke found some particular minerals and their journey.

On 13 November 1819, Stromeyer presented his chemical analyses of these minerals from Greenland at a Meeting of the Royal Society of Sciences (German: Versammlung der Königliche Societät der Wissenschaften). One of the new minerals, which he named eudialyte, he described as having tremendous exterior likeness with minerals of the garnet group, "especially with the Greenlandic lamellar pyrope" (German: Grönländischen schaligen Pyrop) to which eudialyte was "deceptively similar" ("Dasselbe hat im Aeussern mit den granatartigen Fossilien ungemein viel Aehnlichtkeit, zumahl mit dem Grönländischen schaligen Pyrop, und manche Stücke davon gleichen täuschend 
diesem Fossil", [1], pp. 1998-1999). How could Stromeyer be certain that he was dealing with a new mineral, and not this highly similar so-called Greenlandic garnet? Can we, today, be sure Stromeyer provided the original account of a new mineral, rather than redefining an already described mineral? Clearly, we first have to know more about the mineral known as the Greenlandic garnet.

\section{Massive, Lamellar Garnet from Greenland}

As far as I have been able to find, the first mention of a garnet specifically from Greenland is by French chemist Antoine François de Fourcroy (born: 15 June 1755 in Paris-died: 16 December 1809 in Paris) in 1799 in a summary of scientific correspondence with several foreign researchers [8]. Among these summaries is a description of an incoming collection of minerals from Norway and Greenland addressed to his student Nicolas-Louis Vauquelin (born: 16 May 1763 in Saint-André-d'Hébertot-died: 14 November 1829 in Saint-André-d'Hébertot) for further chemical investigation, sent by Danish chemist Peter Christian Abildgaard (born: 22 December 1740 in Copenhagen-died: 21 January 1801 in Copenhagen). Abildgaard had presented at the Meeting of the Royal Society of Sciences on 1 February 1799 his findings on titanium ores from Arendal in Norway and also the first chemical analysis of the new mineral cryolite from Greenland $[9,10]$. The primary pieces in the mineral collection sent to Vauquelin were naturally the minerals from Arendal and the cryolite from Greenland, but the package also contained a sample of "massive garnet from Greenland" (French: Grenat en masse du Groënland; the meaning of "grenat en masse" is probably a "mass of indistinct or multiple garnets" [11]), which "seems to differ a lot from true garnet" (Fourcroy [8], p. 195: "№ 8. Grenat en masse du Groënland. Il paroít différer beaucoup du véritable grenat, puisqu'il est presque infusible au chalumeau". Fourcroy later mentions a "lamellar" grenat en masse "whose pyramids do not terminate" ("Le grenat en masse lamelleuse et le grenat informe dont les pyramides ne sont pas terminées") as one of five forms in which garnet naturally occurs ([12], p. 297).

While Fourcroy's student Vauquelin, a revered mineral chemist, over the years produced analyses of various garnets, it seems that he did not specifically publish the results of his analysis of the Greenlandic garnet or did not analyse it. Neither did Abildgaard himself, as far as I can find, publish any work on the Greenlandic garnet before his demise in 1801. As such, this short thread is probably already a dead end. However, on a parallel track, "Grenat en masse du Groenlande" is also mentioned by mineralogist Prince Dimitri de Gallitzin [13]; someone who deserves a longer introduction to fully appreciate his statement.

\subsection{Prince Gallitzin and the Greenlandite}

Prince Dimitri de Gallitzin (born: 21 December 1728 in Saint Petersburg-died: 16 March 1803 in Brunswick; "de Gallitzin" is the Frenchified spelling of his Russian name Dmitriy Alekseevich Golitsyn [14]) was a Russian prince and foreign diplomat. During the 1760s, Gallitzin lived in Paris, where he became well acquainted, among other high-ranking persons, with the Encyclopédistes Denis Diderot, Jean-Baptiste le Rond d'Alembert, and Voltaire [15]. In 1769, Gallitzin became the Russian Ambassador in The Hague, Dutch Republic. In 1782, he was downgraded to Ambassador in Turin, a position from which he soon resigned and he moved back to The Hague in 1783, where he dedicated his time to science. He lived there until 1793, when the French Revolutionary Wars swept through Europe. He fled the country with his library, laboratory, and mineral collection shortly before the Northern Netherlands were invaded, and settled in Brunswick, Germany [14] (Figure 1).

Gallitzin was an avid mineralogist and mineral collector, and a fellow of prestigious scientific societies across Europe. He became inspired by the five encyclopaedic volumes of Histoire Naturelle des Mineraux by the encyclopédiste Georges-Louis Leclerc de Buffon (born: 7 September 1707 in Montbart-died: 16 April 1788 in Paris), whom Gallitzin knew in Paris and corresponded with for many years. In 1792, Gallitzin published the first edition of his collection of brief descriptions of minerals, Traité ou Description Abrégée et Méthodique des Minéraux, in which he had attempted to classify the then known mineral wealth into distinct groups [16]. The entry for the garnet group does not contain any 
mention of a species from Greenland, neither is it mentioned in the new and revised version of the Traité [17]. With respect to Gallitzin's ambitiousness and the scope of his works, it indicates that the Greenlandic garnet variety was unheard of until at least 1796.

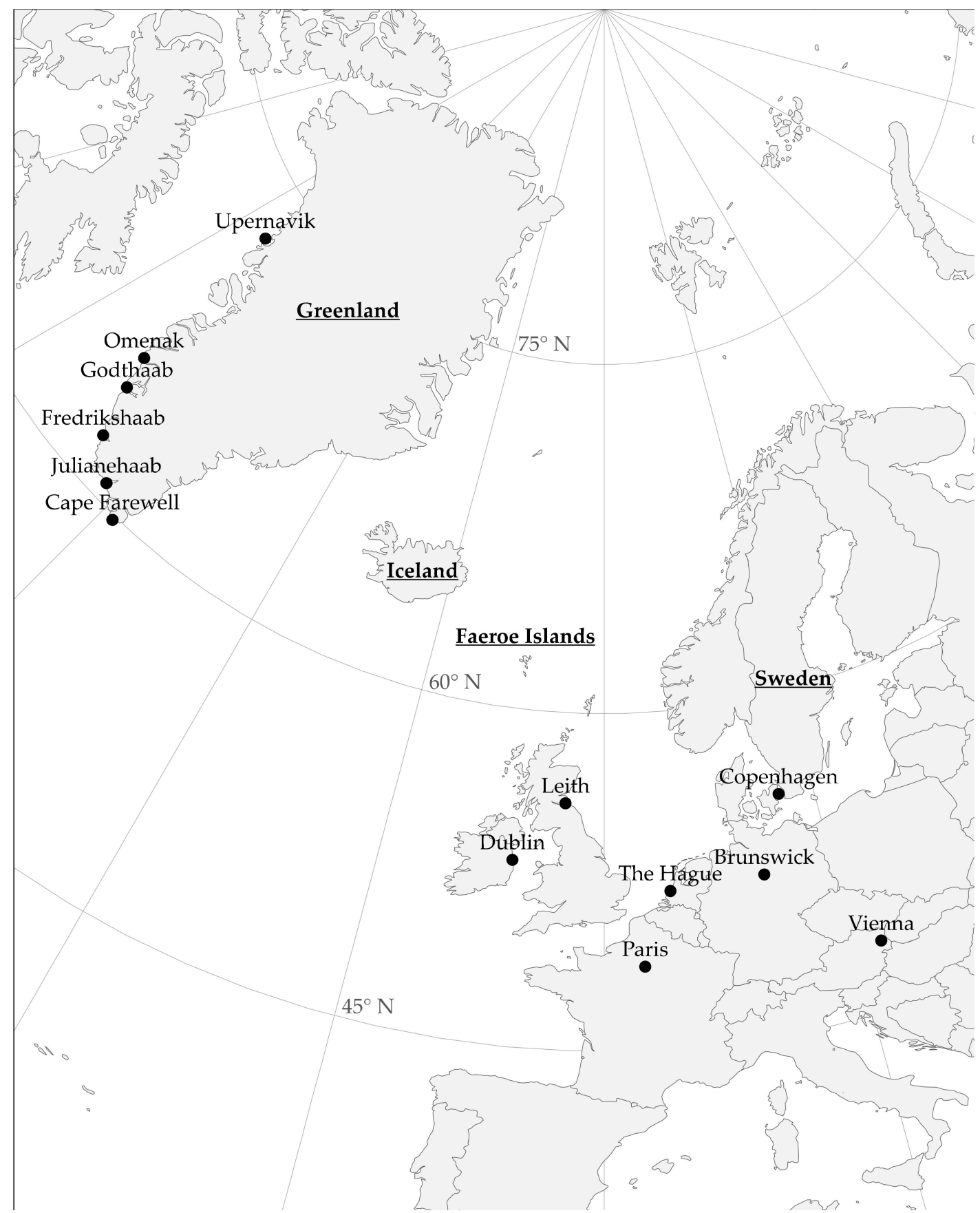

Figure 1. Map of Europe and Greenland with the names of important places pertaining to Prince Dimitri de Gallitzin and Karl Ludwig Giesecke. Original map credit: Chen-Pan Liao (CC BY-SA 4.0), the map has been adapted.

Despite Gallitzin's poor health, in 1799 he took on the role of President of the Mineralogical Society in Jena, but could not attend his own inauguration [14]. From his home in Brunswick, Gallitzin worked on his masterpiece, Recueil de Noms par Ordre alphabetique apropriés en Mineralogie [13], which appeared in 1801 and is in essence a full encyclopaedia of mineralogy from that time. This time, however, 
the entry on the garnet group contains a description of Grenat en masse du Groenlande. Although he does not mention the source of this garnet variety, it is tempting to think, especially considering the identical nomenclature and emergence in time, that this is the same garnet variety as the one sent to Vauquelin by Abildgaard in 1799.

The odd Greenlandic garnet interested Gallitzin enough to send a sample of it for chemical analysis to Johann Bartholomäus Trommsdorff (born: 8 May 1770 in Erfurt-died: 8 March 1837 in Erfurt). Whether Gallitzin received the mineral from Vauquelin through his French connections, directly from Abildgaard himself, or from another source, is not known. Trommsdorff was a skilled chemist and one of the pioneers of modern pharmacology. From his chemical analysis, Trommsdorff came to the striking conclusion that the Greenlandic mineral contained 10 percent by weight of zirconium oxide [18], an element that until then was only known to occur in the mineral zircon [19]. The modern reader will realise that a garnet-like mineral from Greenland with 10 percent by weight of zirconium oxide possibly describes the mineral eudialyte, 18 years before Stromeyer [1].

Trommsdorff called the mineral "dense hyacinth" (German: dichter Hyacinth; hyacinth is an old name for gem zircon) [18]. Unaware of kimzeyite [20], Gallitzin subsequently concluded on account of the Greenlandic mineral's substantial zirconium content that it did not belong to the garnet group, and revised his garnet classification in the second release of Recueil [21]. He named the mineral greenlandite (French: Groenlandite).

Due to degrading health and personal economy, Gallitzin donated his mineral collection to the Mineralogical Society in Jena in 1802. The exact contents of the collection are no longer known, but it impressed on contemporaries for its rare and large specimens from all over the world. The shipment from Brunswick to Jena weighed $1850 \mathrm{~kg}$ [14].

\subsection{Further Studies of Greenlandite}

After Gallitzin's death, the report of zirconium in greenlandite sparked an interest. Johann Ludewig Wilhelm Gruner (1771-1849) [22] criticised Trommsdorff [18] for giving an insufficient account of the mineral. Gruner's specimen was not sent by Gallitzin or Abildgaard, but rather he obtained it from an unnamed travelling Danish mineralogist. The physical descriptions match, and an unnamed friend of Gruner from Göttingen, who saw Trommsdorff's specimen in person, assured him that they were the same mineral. In addition to finding calcium in the mineral, Gruner reached the same conclusion as Trommsdorff [18] and reported that 11 percent zirconium oxide was present in the red lamellar garnet from Greenland [22] (lamellar" is here chosen as translation of the German "blättrig", which also could be translated as "leafy" and is this similar to "foliage" and its derivation "foliated". Since Fourcroy [12] used the French "lamelleuse" do describe the same mineral variety, "lamellar" seems like a more unified translation). Thus, there are two independent sources that claim to have found similar amounts of zirconium oxide in a garnet-like mineral from Greenland.

After a few years, Martin Heinrich Klaproth (born: 1 December 1743 in Wernigrode-died: 1 January 1817 in Berlin) entered the debate. Klaproth was a chemist and probably the best analyst of minerals, whose mineral analyses were highly regarded also by Gallitzin for being particularly accurate [23,24]. Since Klaproth originally discovered the chemical element zirconium in its namesake zircon [19], he is to be regarded as an expert on the matter.

Klaproth performed a chemical analysis of a specimen of Gallitzin's garnet-like mineral. He found "not a trace of zirconium" in the mineral (German: ohne alle Spur von Zirkonerde) [25] (p. 135). Despite the challenging result of his analysis of a sample from the same source (Gallitzin) as Trommsdorff [18], he ended his polite disputation by raising that it is still "possible that on Greenland there could be a physically similar garnet species, which really does contain zirconium in its mixture" "'Ob nun gleich die Resultate meiner Untersuchung nicht mit denen übereinstimmen, welche die Herren Trommsdorf (sic) und Gruner mitgetheilt haben, so halte ich mich doch nicht berechtigt, die Richtigkeit der letztern unbedingt zu bestreiten; da bei aller Uebereinstimmung des von mir untersuchten Fossils mit der, von Jenen gegebenen, äussern Beschreibung der ihrigen, es doch möglich ist, dass in Grönland eine 
im Aeussern ähnliche Granatart vorkommen könnte, die in ihrer Mischung wirklich Zirkonerde enthalte" [25], p. 137). He named the mineral "scaly pyrope" (German: schaliger Pyrop; one must be mindful of the differences in historical garnet nomenclature compared to modern nomenclature-the same mineral would be classified as almandine today, since it contains more iron than magnesium). In Handbuch der Mineralogie, Hausmann ([26], p. 598) regarded the "Klaprothian analysis" as a final debunking of the zirconium in garnet from Greenland reported by Trommsdorff [18] and Gruner [22]. However, rather than settling the debate, Klaproth's analysis also became a cause for confusion.

In Chemische Untersuchungen, John [27] described a "new Nordic mineral" from Arendal. According to him, the titanium-rich mineral, which later turned out to be garnet [28], contained a significant but uncertain amount of zirconium. Christoph Heinrich Pfaff (born: 2 March 1773 in Stuttgart-died: 23 April 1852 in Kiel) [28] obtained samples of both John's mineral and the Greenlandic "schaaliger Pyrop" from the mineral trader Nepperschmidt and performed his own chemical analyses of both. Pfaff could reproduce Klaproth's [25] analysis of the greenlandite and also found no zirconium. Pfaff further argued that John's amount of zirconium should really be taken for titanium, and he discussed the similarities of these two elements and the difficulties in distinguishing them from each other [28].

Pfaff [28] oddly concluded that Trommsdorff [18] and Gruner [22] had analysed a mineral similar to John's [27] titanium garnet from Arendal, and thus did not find zirconium but titanium, whereas Klaproth [25] had analysed the true Greenlandic garnet, which did not contain zirconium or titanium. Since Trommsdorff and Klaproth both received their samples from Gallitzin, which Pfaff must have neglected, this is an unsatisfactory explanation. However, he would not be the only one to draw this conclusion.

So far, despite ambiguous reports, it seems unlikely to me that greenlandite is in fact eudialyte. To further evaluate this hypothesis, I wanted to try to find out the source locality of this Greenlandic garnet. If the garnet came from a part of Greenland that does not match the location of an alkaline complex, it cannot be eudialyte. To lead up to this, we will go back in time a little to follow the earlier-mentioned Karl Ludwig Giesecke for a while, whose journey intersects the above storyline a number of times.

\section{Karl Ludwig Giesecke's Journey}

In the year 1800 or 1801 [7], Karl Ludwig Giesecke apparently gave up his life in theatre and left Vienna in debt with distraint levied for non-payment of rent to pursue a career in mineralogy as a mineral trader, an interest he had kept up next to theatre, and soon he was well connected and widely respected among scientists across Europe [6]. For a few years, he travelled and met influential scientists of the day, including some earlier mentioned names. In 1801 he travelled around Germany and met, among others, Martin Heinrich Klaproth in Berlin and also travelled to Brunswick to meet Prince Dimitri de Gallitzin. In 1803 and 1804, he travelled north and visited places in Denmark and Sweden [7] (Figure 1).

With support from the Danish state, Giesecke undertook a mineralogical expedition to the Faeroe Islands, 8 August to 14 September 1805, and during the following Winter he studied the samples and compiled his findings in a written presentation. The results from this study impressed the Danes and he was granted permission to undertake a similar study of the mineral wealth of Greenland, which until then had not yet been visited by any mineralogist. Despite not being fully aware of the seasonal and logistic challenges of such an undertaking, it was Giesecke's original plan to explore all of the inhabited West Greenland in two and a half years [6].

Giesecke arrived in Fredrikshaab (Paamiut) in southwestern Greenland on 31 May 1806. He wasted no time and already the next day he documented the rocks in the area. His first excursions would be to the Julianehaab District (Qaqortoq), where the ship lay anchor in the Kakortok Fjord on 9 July. Using Julianehaab as a base, he made first a four-week-long survey of the coast to the south, and then a one-week journey to Igalikko northeast of Julianehaab. When he returned on 22 August, he was forced to stay for four days due to bad weather conditions and ice [4]. 
On 27 August he left Julianehaab and reached the end of the Kangerluarsuk Fjord in the evening and pitched camp below the Nunasugsuk (Nunasarnausak) mountain. The following day, through mist and rain, Giesecke explored the outcrops around the fjord and found a "peculiar granite blend with red garnet, pale-green and yellowish, corundum-like feldspar, black hornblende, star-shaped actinolite, and a green, easily weathered mineral crystallised into the shape of garnet" ("Am Fusse ist angelehnt ein besonderes Granitgemenge mit rothem Granat, lauchgrünen und gelblichen, korundähnlichem Feldspath, schwarzer Hornblende, sternförmigem Strahlstein, und einem grünen, leicht verwitternden, granatförmig kristallisirten Fossile, seltener noch mit einer pfisichblüthenrothfarbenen, fettglänzenden, dem Feldspath ähnlichen, blätterigen Steinart, welche die hohe Farbe auf frischem Bruche sogleich beinahe ganz verliert. Beträchtliche Lager von grauem, zuweilen labradorisirendem Feldspath findet sich in dieser ganzen Gegend. Der Basalt mit eingewachsenen Feldspathkrystallen durchschneidet den Berg horizontal und vertikal. Ich verirrte mich des dicken Nebels wegen, fans mich aber doch wieder, obgleich mit vieler Mühe, zurecht und kam Abends gegen $10 \mathrm{Uhr}$ müde und durchnässt wieder zum Zelte zurück." [4], p. 33). He got lost in the thick fog, but late in the evening found his way back to the tent, wet and tired. The entire next day he wandered around the area on both sides of the fjord [4]. Plainly, Giesecke spent two days exploring the enigmatic peralkaline syenitic rocks that constitute what we today call the Ilímaussaq alkaline complex [29]. The "red garnet" that he found eventually would become the type specimen for eudialyte.

The first year Giesecke only surveyed the Julianehaab and Fredrikshaab Districts in southern Greenland, including the southernmost tip at Cape Farewell. In the second year he made his way up the western coastline and travelled as far north as Upernavik [4]. His survey spanned a remarkable stretch from $59^{\circ}$ to $72^{\circ}$ North.

In August 1807, England declared war on Denmark in what is known as the Second Battle of Copenhagen. While Denmark was then a small and independent neutral state during the Napoleonic Wars, in a pre-emptive strike, its entire fleet was confiscated by England to avoid the Danish ships falling into the hands of Napoleon [30]. Giesecke was practically stranded on Greenland due to the following logistic complications. In the bombardment of Copenhagen, all of Giesecke's belongings-books, manuscripts, minerals including his collection from the Faeroe Islands-left behind in the city were destroyed [6], which he only found out about on 28 May 1809 while on Greenland [4].

After two years work on Greenland, Giesecke shipped off his collected mineral samples, which filled about nine or ten barrels and boxes, toward Copenhagen, packaged in dry moss [31]. On 15 May 1808, a letter out of London brought the tragic news to Giesecke that the ship Der Freuhlin that transported his collection had fallen into the hands of the English on the journey between Iceland and Denmark [4] (p. 97) [32]. Two months later, on a rainy and stormy day, Giesecke had a chance to leave Greenland, but the ship was in poor condition and overladen with homebound colonists. Thus, he decided to stay on Greenland for another year instead of sailing home, fuelled by his determination to renew his precious collection, "since the sour fruits of my hitherto applied efforts largely have fallen into English hands" ("14. Juli stürmte es aus Südwest mit vielem Regen. Da Kapitän Quale's Schooner von Farsund bereits mit Colonisten, welche nach Hause reisen sollten, überladen war, und weder das Schiff in ganz gutem Zustande, noch die überigen Aussichten für meine Reise sehr günstig waren, so beschloss ich noch ein Jahr in Grönland zuzubringen und noch so viel möglich zu untersuchen und einzusammeln, da die sauren Früchte meiner bisher angewandten Mühe grösstentheils in englische Hände gefallen sind." [4], p. 112). His stay would eventually extend to seven and a half years.

Giesecke specifically did return to the Kangerdluarsuk Fjord on 19 July 1809, and this time set up camp at the end of the fjord, where the eudialyte-bearing alkaline rocks are found. The next day, Giesecke and a companion spent the entire day hiking around the area [4]. Presumably they collected new samples of the exotic syenitic rocks that must have fascinated Giesecke as a mineralogist.

While Giesecke was still on Greenland, his captured mineral collection was brought to Leith, a port of Edinburgh, Scotland. The precious but unlabelled rock samples endured a rough treatment and eventually lay strewn across the floor of a warehouse and were a "spectacle of uninviting rubbish" 
([31], p. 100) that interested no one, including esteemed mineralogists Thomas Charles Hope, Robert Jameson, and John Murray [33]. The exact origin of the minerals was unknown, until Thomas Allan of Lauriston (17 July 1777 in Edinburgh-12 September 1833 in Linden Hall), who keenly spotted that the rocks and minerals could not have come from volcanic Iceland, recognised among the rubbish a good amount of the rare new Greenlandic mineral cryolite and so determined the collection's country of origin. Allan bought the entire collection for $£ 14.10$ [33], while he estimated the value of the cryolite alone would be in excess of $£ 5000$ (approximately equivalent to $£ 400,000$ today [34]). After he had discarded half the unlabelled collection as useless common rocks, the remaining mineral specimens contained among others cryolite, apatite, tourmaline, and a few different forms of garnet, including a variety that was new to Allan and "belongs to a group which had been embedded in sodalite, and accompanied by augite" ([31], p. 103).

The minerals in the exciting new collection from Greenland were expeditiously studied by Thomas Allan and Thomas Thomson (born: 12 April 1773 in Crieff-died: 2 July 1852 in Kilmun). Allan described a mineral that he suspected to be gadolinite [33], but Thomson's chemical analysis revealed that it was a new mineral species, rich in cerium, which he named allanite for Thomas Allan [35]. Thomson also discovered and named sodalite, which occurred in a rock with a garnet-like mineral. "The particular colour and appearance of this garnet shows, that the rock came from Greenland: for similar garnet has never been observed, except in specimens from Greenland" ([36], p. 288). To me, an extraordinary reference to greenlandite, here demonstrably used to describe a eudialyte-bearing rock from the Ilímaussaq alkaline complex.

Due to the mediocre state of the mineral collection when Allan first encountered it, he assumed it could not have been assembled by a skilled mineralogist. His enquiries to identify the collector were unfruitful, until in 1812 a travelling Danish mineralogist, Morten Wormskiold, enlightened Allan with the minerals' true origin and the fate of Giesecke, who then still resided on Greenland but was bound for Leith in 1813. As soon as Allan heard of Giesecke's arrival in Leith on 19 September 1813, he immediately went to see the returning traveller and informed him of what had happened with the lost mineral collection. In the spirit of a true scientist, Giesecke was pleased that the minerals, which he had thought were lost, had been used for their intended purpose. Giesecke lived with Allan for some time and went through his old collection and completed it for Allan with specimens from his new collection. Allan interested Giesecke in a candidature for a professorship in mineralogy in the Dublin Society, and in part through Allan's efforts and connections Giesecke was elected for the position [33]. From his new placement in Dublin, Giesecke distributed minerals from his Greenland collection to chemists and mineralogists across Europe.

\section{The Mineral that is Easily Dissolved}

In 1819, Friedrich Stromeyer, a doctoral student of Nicolas-Louis Vauquelin, presented his analytical results from a few Greenlandic minerals_-"gieseckite" (muscovite pseudomorph), sapphirine, apophyllite, "dichroite" (cordierite), aragonite, and eudialyte—that he received from Giesecke [1,2]. Stromeyer named the red mineral from Kangerdluarsuk eudialyte, which roughly translates to "easily dissolved" in Greek, since it gelatinises readily in contact with acids. Stromeyer noted that the red mineral was exceptionally similar to minerals of the garnet group, especially the Greenlandic garnet ("Eudialyt von Kangerdluarsuk. Dieses Fossil findet sich in demselben Lager, worin auch der Sodalit vorkommt. Dasselbe hat im Aeuzern mit den granatartigen Fossilien ungemein viel Aehnlichkeit, zumahl mit dem Grönländischen schaligen Pyrop, und manche Stücke davon gleichen täuschend diesem Fossil" [1], pp. 1998-1999). Stromeyer's analysis of the mineral shows it contained 10.8968 percent by weight zirconium oxide. After zirconium was discovered in zircon by Klaproth thirty years earlier [19], Stromeyer's eudialyte is the first additional mineral in which zirconium was reliably determined.

Pfaff soon also presented a chemical analysis of Giesecke's mineral from Greenland, which in essence corresponded well to Stromeyer's analysis, but he added a small amount of copper and claimed 
the likely discovery of a new element similar to tantalum: "tantaline" [37]. However, he himself soon corrected that tantaline was not a new element found in eudialyte, but rather should be taken for silica [38]. Stromeyer doubted Pfaff's determination of copper and could not replicate it himself, and suggested that the copper was derived as contamination from Pfaff's silver crucible [39].

Despite the fact that Klaproth's analysis of the greenlandite revealed no zirconium content [25], the discovery of a garnet-like mineral from Greenland that contained zirconium led to some confusion. A decade after eudialyte's discovery, Weiss described its crystal structure, but also commented "are Trommsdorff's "dichter Hyacinth" and Gruner's garnet really eudialyte?" ([40], p. 197). Similarly, in Rammelsberg's alphabetical handbook of mineralogy the entry for eudialyte declares that the mineral was first analysed by Trommsdorff and then Gruner, after which both Pfaff and Stromeyer analysed it, seemingly as if they were unaware of the earlier works [41]. Furthermore, the entry for the garnet group contains the Greenlandic garnet that Klaproth [25] and Pfaff [28] analysed, "not to be confused with the so-called schaliger Pyrop of Trommsdorff and Gruner, which is eudialyte" ([41], p. 277). Is there any substance to these convoluted connections between greenlandite and eudialyte?

\section{Greenlandite: Garnet or Eudialyte?}

Immortalised by the scanner, in one of the digitalised versions of the first edition of Recueil [13] the entry for garnet was edited by one of the book's owners: "The massive garnet from Greenland, is not a garnet," (Figure 2). In addition, an entry for greenlandite was added to the lithological table in the appendix with Trommsdorff's analysis [18], to update it according to Gallitzin's second version of Recueil [21].

(a)

\section{Le Grenat en masse du Groenlande, pourroit bien ne pas être un Grenat, puisqu'il est presqu' infusible au Cha- lumeau.}

(b)

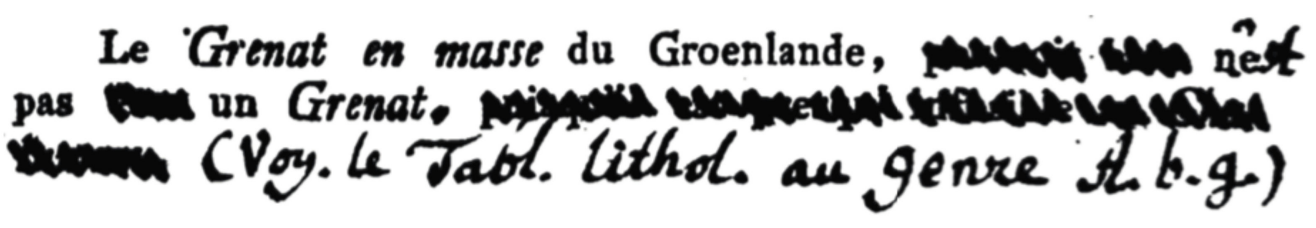

Figure 2. A snippet from Gallitzin's entry on the garnet group in Recueil ([13], p. 116): (a) Gallitzin's original text; (b) The edit made by one of the book's subsequent owners, claiming that greenlandite is not a garnet.

\subsection{Verification by Modern Analysis}

Multiple sources suggested that Gallitzin's greenlandite was in fact eudialyte [40,41]. Although Klaproth was known for his accurate mineral analyses, it seems too easy to fully discredit the zirconium in greenlandite based only on his good reputation. Maybe Klaproth did not analyse the same mineral as Trommsdorff and Gruner?

Even though Klaproth's and Trommsdorff's samples were supposedly identical, greenlandite can reasonably only be eudialyte if, for whichever reason, they actually were not the same material due to an oversight at some point between the outcrop and crucible. Since Klaproth's analysis contains no trace of zirconium [25], and differs significantly from Trommsdorff's and Gruner's results [18,22], is there a reason to assume that they were different? Regardless, re-examining Klaproth's sample cannot verify Trommsdorff's and Gruner's zirconium analyses.

To settle the discourse with the highest degree of certainty, Trommsdorff's original sample material could be reanalysed by modern (non-destructive) analytical methods, such as X-ray diffraction or Raman spectrometry, to verify its identity as garnet or eudialyte. Unfortunately, the Trommsdorff 
family does not keep any of Johann Bartholomäus Trommsdorff's mineral samples in its collection anymore [42], which means this option is not available.

Gallitzin provided the sample to Trommsdorff, but there is no mention by either of them of the sample locality or a source $[13,18,21]$. Additionally, there is no single letter from Prince Dimitri de Gallitzin among the preserved personal letter correspondence addressed to Trommsdorff, who burned a great number of his letters in Napoleonic times [42]. When Trommsdorff met Napoleon Bonaparte in 1807, the Emperor asked him who he saw as the greatest chemist, to which he answered: "Chemistry has not had a great head since Lavoisier lost his" ("Die Chemie hat kein grosses Haupt mehr, seit Lavoisier das seinige verloren" [43], p. 125), referring to the execution of Lavoisier by guillotine in 1794 during the French Revolution. Prince Dimitri de Gallitzin, a nobleman like Lavoisier, was a critic of the Revolution [17]. Presumably, this was reason enough for Trommsdorff to destroy Gallitzin's letters out of precaution.

As mentioned, near the end of his life, Gallitzin donated his vast mineral collection to the Mineralogical Society in Jena. The Society closed in the 1890s and the castle where the mineralogical collection was kept was demolished in 1908. Gallitzin's collection was moved to another storage, but unfortunately it perished in a bomb attack in 1945 during the Second World War ([14] and references therein). Thus, also the second option to study the original greenlandite is no longer possible.

Gruner seems to have been a more low-profile person, and his belongings likely will not have survived into the modern age. Therefore, sadly, it appears to be impossible to determine with absolute certainty from the original sample material whether greenlandite was in fact eudialyte or just garnet.

\subsection{Chemist Versus Chemist}

Speculating about the quality of each respective chemist's analyses is perhaps the third best option. If there is enough reason to doubt Trommsdorff's result, perhaps Klaproth was right and thus greenlandite ought simply to be taken for garnet. Citing Gallitzin, "I will not interfere in judging chemists: I will only allow myself to observe that at least the presumption is strongly in favour of Mr. Klaproth, who, following the example of his predecessors, did not give any result without also exposing the path he had followed and the processes he had observed: he had put everyone in the position of verifying them" ("Je ne m'ingérerai point en juge des chimistes; je me permettrai seulement d'observer, que du moins la présomption est forte en faveur de Mr Klaproth, qui à l'exemple de ses prédécesseurs, n'a donné aucun résultat, qu'il n'ait en même temps exposé la marche qu'il avoit suivie et les procédés qu'il avoit observés: il a mis par-la chacun à portée de les vérifier" [24], pp. 9-10). Gallitzin held Klaproth, along with Vauquelin, in high regard.

Gallitzin understood the importance of chemistry in furthering mineralogy, which until the end of the 18th century had consisted largely of physical descriptions based on ocular observations. For example, leucite ("white garnet") used to be classified in the garnet group on account of its highly similar crystal habit. Klaproth's analysis revealed, in addition to silica and alumina, that it contained a large amount of potassium, an element that had not previously been encountered in inorganic minerals [24,44]. Suddenly, leucite began to lose its close relations with the garnet family, which is an example of the enormous contributions quantitative chemistry made to mineralogy. On the topic of the reclassification of minerals in the garnet group, Gallitzin wrote: "It may be that I am mistaken, but it seems to me that here chemistry can and must judge, and decide peremptorily; especially when two as knowledgeable and exact chemists as Mrs. Klaproth and Vauquelin will be involved ("Il se peut que je me trompe, mais il me semble qu'ici la Chimie peut et doit juger, et decider peremptoirement; surtout lorsque deux aussi savans et exacts chimistes que le sont Mrs. Klaproth et Vauquelin, vaudront s'en mêler" [21], p. 145).

At the same time, Gallitzin was highly critical of other chemists and the quality of their analyses. He wrote, "For, whether the chemists have not yet discovered the proper ways to lead them to the knowledge of the nature of the constituent parts of minerals, or for some other reason that I do not know, the results of their respective analyses are so inconsistent with each other, that we do not know 
now what to do with everything they did and said about minerals" (Car, soit que les chimistes n'ayent pas encore découvert des agens propres à les conduire à la connoissance de la nature des parties constituantes des minéraux, soit par quelques autres causes que j'ignore, les résultats de leurs analyses respectives sont si peu concordans entre eux, qu'on ne sait plus maintenant à quoi s'en tenir sur tout ce qu'ils ont fait et dit sur les minéraux" [24], pp. 3-4).

Trommsdorff's record is not as impeccable as Klaproth's. In 1800, Trommsdorff announced that, in addition to Vauquelin's newly discovered "Glucine" (= beryllium oxide) in the mineral beryl [45], he had found another new element in his own beryl specimen from Saxony, which he called "Agusterde" [46]. Vauquelin determined that the hexagonal mineral that Trommsdorff had analysed was in fact mainly composed of calcium phosphate [47], and thus was not beryl but apatite!

This was an exciting time in chemistry, when scientific frontiers were rapidly advancing and the elements of the periodic table were being discovered. Some chemists, such as Trommsdorff [46] and also Pfaff [37], presumptuously claimed to have found new elements that soon were discredited. To me, such chemists are less trustworthy.

\subsection{Distinction by Dissimilarities}

The relationship between greenlandite and eudialyte is chiefly based on their similarities: red colour and approximately the same content of zirconium, the latter of which has been disputed. A more robust verification could be based on comparing critical dissimilarities in physical and chemical characteristics of the two minerals.

Most obviously, eudialyte dissolves readily in acids without added heat during digestion, which substantially distinguishes it from garnet [1,39]. Gruner claimed that $21 \mathrm{~g}$ out of 100 of the pulverised and ignited sample dissolved in $1.5 \mathrm{Oz}$ hydrochloric acid and $0.5 \mathrm{Oz}$ nitric acid (aqua regia) after $9 \mathrm{~h}$ under intense heat [22]. This is not nearly enough: only a gelatine of silica corresponding to approximately $50 \mathrm{~g}$ per 100 should remain if it were truly eudialyte.

While the analyses of Trommsdorff and Gruner contain eudialyte-like concentrations of zirconium oxide [18,22], there is no detailed agreement between their analyses with respect to the other elements (Table 1).

Table 1. Compiled chemical analyses of greenlandite and eudialyte by various analysts.

\begin{tabular}{|c|c|c|c|c|c|c|}
\hline Analyst & \multicolumn{4}{|c|}{ Greenlandite } & \multicolumn{2}{|c|}{ Eudialyte } \\
\hline $\mathrm{SiO}_{2}$ & 50 & 30.75 & 43 & 41.82 & 52.4783 & $54.10^{1}$ \\
\hline $\mathrm{Al}_{2} \mathrm{O}_{3}$ & 28 & 30.50 & 15.50 & 17.82 & & \\
\hline $\mathrm{CaO}$ & & 7 & 1.75 & 0.80 & 10.1407 & 10.80 \\
\hline $\mathrm{MnO}$ & & & 0.50 & 3.12 & 2.5747 & 2.93 \\
\hline $\mathrm{Na}_{2} \mathrm{O}$ & & & & & 13.9248 & 11.40 \\
\hline $\mathrm{CuO}$ & & & & & & 0.92 \\
\hline $\mathrm{HCl}$ & & & & & 1.0343 & 0.30 \\
\hline $\mathrm{H}_{2} \mathrm{O} /$ L.O.I. ${ }^{2}$ & 6 & 4.75 & & & 1.8010 & 1.66 \\
\hline
\end{tabular}

The full table of their analyses shows substantial differences also with Stromeyer's eudialyte. Klaproth's analysis of greenlandite [25] was fairly accurately reproduced by Pfaff [28], who also reported an analysis of eudialyte similar to Stromeyer's [1,37].

The specific gravity of eudialyte given by Stromeyer is 2.90355 [39]. The same dimensionless property for greenlandite has been reported as 40.000 (sic) [21], 3.827 [22], 3.920 [25], and 3.634 [28]. Greenlandite is consistently much denser than eudialyte, and similar to garnet. 
Stromeyer noted that eudialyte melted instantly in front of the blowpipe, and in addition small pieces melted in a spiritus flame, a property that distinguishes it from garnet [39]. Fourcroy noted that greenlandite seemed different than other garnets, since it is infusible by the blowpipe [8].

In conclusion, the dissimilarities between greenlandite and eudialyte outnumber the similarities, and thus the greenlandite most likely was not eudialyte.

\subsection{The Source of Greenlandite}

Perhaps the best indication of the true identity of greenlandite (known by many names, summarised in Table 2) came from Karl Ludwig Giesecke. His descriptive catalogue of minerals available from the museum in Dublin, although it is missing eudialyte, contains a few specimens of minerals labelled as "Aumaursak, Precious Garnet, Lamellar Garnet, Greenlandite, Foliated Pyrope". The first two sample localities are in Greenland, and these minerals were undoubtedly collected by Giesecke himself. They are from Akudlerne in the Firth of Omenak (Uummannaq), and from Auaitsirksarbik in South Greenland ([48], p. 13). Auaitsirksarbik lies inland toward the glacier from the end of the Ameralik Fjord, which leads to Godthaab (Nuuk). Neither of these sites is the location of a peralkaline igneous intrusion and thus the garnets cannot be eudialyte.

Table 2. Compiled list of names used by different scientists to denote greenlandite and eudialyte.

\begin{tabular}{|c|c|c|c|}
\hline Scientist & Name & Source & Identity \\
\hline Fourcroy $[8,12]$ & Grenat en masse du Groënlande & Abildgaard & Garnet \\
\hline Gallitzin [13] & Grenat en masse du Groenlande & Unknown & Garnet \\
\hline Trommsdorff [18] & Dichten Hyacinth & Gallitzin & Garnet \\
\hline Gallitzin [21] & Groenlandite & Unknown & Garnet \\
\hline Gruner [22] & $\begin{array}{l}\text { Rothen blättrigen Granat aus Grönland, } \\
\text { blättriger Hyacinth }\end{array}$ & Danish mineral trader & Garnet \\
\hline Giesecke $[4,5]$ & Rothen Granat & Kangerdluarsuk, South Greenland & Eudialyte \\
\hline Giesecke $[4,5]$ & Grönländische Granat & Auaitsirksarbik, West Greenland & Garnet \\
\hline Klaproth [25] & Schaliger Pyrop & Gallitzin & Garnet \\
\hline Pfaff [28] & Schaaliger Pyrop & Nepperschmidt & Garnet \\
\hline Allan [31] & Garnet embedded in sodalite & Giesecke & Eudialyte \\
\hline Thomson [36] & Garnet from Greenland & Giesecke & Eudialyte \\
\hline Stromeyer $[1,2,39]$ & Eudialyte & Giesecke & Eudialyte \\
\hline Stromeyer $[1,2,39]$ & Grönländischen schaligen Pyrop & - & Garnet \\
\hline Pfaff [37] & Eudyalith & Giesecke & Eudialyte \\
\hline Giesecke [48] & $\begin{array}{l}\text { Aumaursak, Precious Garnet, Lamellar } \\
\text { Garnet, Greenlandite, Foliated Pyrope }\end{array}$ & $\begin{array}{l}\text { Auaitsirksarbik, South Greenland; } \\
\text { Akudlerne, West Greenland }\end{array}$ & Garnet \\
\hline
\end{tabular}

Giesecke reached Auaitsirksarbik on 1 June 1810. The dominant rock type he called a mica schist, which crumbled to gravel and sand at the slightest blow. Throughout this rock he found a lamellar mineral that he recognised and described specifically as the Greenlandic garnet in his journal [4]. Since Giesecke met Gallitzin in his home in Brunswick [7], perhaps he had seen the original greenlandite since he could so explicitly identify the mineral years later in the field on Greenland. Giesecke described that the greenlandite occurs as bulky and bulbous shapes, rarely as distinct garnet dodecahedra. Their masses range from pea-sized to clumps in excess of 50 pounds. Fragments of these garnets were continually brought to the colony by reindeer hunters [4], whence they found their way into the cabinets of European mineralogists and chemists and for a long time would be mistaken for eudialyte.

Funding: This work is part of a PhD project by the author, which is funded by a grant awarded to Thomas Zack by the Swedish Geological Survey (diary No. 36-1789/2014).

Acknowledgments: This work was done to commemorate the two-hundredth anniversary of the first description of eudialyte. A large volume of historical scientific literature had to be reviewed in the process. This was only made possible by the efforts of institutions that scan and make publicly available old scientific literature, for which the copyrights have expired, which makes it possible to let a computer search these databases for important keywords. If it were not for the open access to scientific literature, this study would have been practically infeasible. Two reviewers provided valuable comments to the manuscript. 
Conflicts of Interest: The author declares no conflict of interest.

\section{References}

1. Stromeyer, F. Analyse einiger grönländischen, von Prof. Giesecke erhaltenen Fossilien. Göttingische Gelehrte Anzeigen 1819, 1819, 1993-2000. (In German)

2. Stromeyer, F. Analyse einiger von dem Prof. von Giesecke in Grönland entdeckten Fossilien: Gieseckit, Saphirin, Apophyllit, Dichroit, Arragonit und Eudialit. Ann. der Phys. und der Phys. Chem. 1819, 63, 372-381. (In German) [CrossRef]

3. Steenstrup, K.J.V. Einleitung und biographische Mitteilungen. Medd. om Grønland 1910, 35, I. (In German)

4. Giesecke, K.L. Bericht einer mineralogischen Reise in Grönland. In Gieseckes Mineralogiske Rejse $i$ Grønland; Johnstrup, F., Ed.; Bianco Lunos Bogtrykkeri: Copenhagen, Denmark, 1878. (In German)

5. Giesecke, K.L. Bericht einer mineralogischen Reise in Grönland. Medd. om Grønland 1910, 35, 1-478. (In German)

6. Johnstrup, F. Indledning med biografiske Meddelelser om Giesecke. In Gieseckes Mineralogiske Rejse i Grønland; Johnstrup, F., Ed.; Bianco Lunos Bogtrykkeri: Copenhagen, Denmark, 1878. (In Danish)

7. Whittaker, A. Karl Ludwig Giesecke: His life, performance and chievements. Mitt. der Österreichischen Mineral. Ges. 2001, 146, 451-479.

8. Fourcroy, A.F. Nouvelles de chimie, Extraites de la correspondence de plusiers savans étrangers, et de l'état de cette science en France. Ann. de Chim. 1799, 32.

9. Scherer, A.N. 3. Vermischte Notizen-12. Norwegische Titanerze und andre neue Fossilien. Allg. J. der Chem. 1799, 2, 502. (In German)

10. Abildgaard, P.C. Om Norske Titanertser og om en nye Steenart fra Grönland, som bestaaer af Flusspatsyre och Alunjord. Det K. Dan. Vidensk. -Selsk. 1800, 3, 305-316. (In Danish)

11. Lemière, B. (Bureau de Recherches Géologiques et Minières, Orléans, France). Personal communication, 8 March 2018.

12. Fourcroy, A.F. Système des Connaissances Chimiques, et de Leurs Applications aux Phénomènes de la Nature et de l'art, 1st ed.; Baudouin: Paris, France, 1801. (In French)

13. de Gallitzin, D. Recueil de Noms par Ordre alphabetique apropriés en Mineralogie aux Terres et Pierres, aux Métaux et Demi-Métaux, et aux Bitumes; avec un précis de leur Histroire-Naturelle, et leurs Synonimies en Allemand: Suivi d'un Tableau Lithologique tracé d'apres les analyses Chimiques, 1st ed.; The orphanage's print: Brunswick, Germany, 1801. (In French)

14. Mokhova, N.A. Dmitriy Alekseevich Golitsyn-Diplomat, Art Critic, Scientist and Collector. New Data on Mineraals 2014, 49, 136-146.

15. Brownson, S.M. Life of Demetrius Augustine Gallitzin, Prince and Priest; Fr. Pustet \& Co.: New York, NY, USA, 1873; pp. 1-444.

16. de Gallitzin, D. Traité ou Description Abrégée et Méthodique des Minéraux, 1st ed.; J. P. Roux \& Compagnie: Maestricht, The Netherlands, 1792. (In French)

17. de Gallitzin, D. Traité de Mineralogie: Ou Description Abrégée et Methodique des Mineraux, 2nd ed.; C. G. Fleckeisen: Helmstedt, Germany, 1796. (In French)

18. Trommsdorff, J.B. Chemische Untersuchung eines hyacinthähnlichen Fossils. Chem. Ann. für die Freunde der Nat. Arzneygelahrtheit, Haushaltkunst und Manufakturen 1801, 67, 433-438. (In German)

19. Klaproth, M.H. Chemische Untersuchung des Zirkons. Beob. und Entdeckungen aus der Naturkunde von der Gesellschaft naturforschender Freunde zu Berlin. 1789, 3, 147-176. (In German)

20. Milton, C.; Ingram, B.L.; Blade, L.V. Kimzeyite, a zirconium garnet from Magnet Cove, Arkansas. Am. Mineral. 1961, 46, 533-548.

21. de Gallitzin, D. Recueil de Noms par Ordre alphabetique Apropriés en Mineralogie aux Terres et Pierres, aux Métaux et Demi Métaux et aux Bitumes; avec un précis de leurs Histoire-Naturelle et leurs Synonymies en Allemand, Latin et Anglois, suivi d'un Tableau Lithologique trace d'aprés les analyses chimiques, , 2nd ed.; The orphanage's print: Brunswick, Germany, 1802. (In French)

22. Gruner, W. Zerlegung des rothen blättrigen Granats aus Grönland. Ann. der Phys. 1803, 13, 491-497. (In German) [CrossRef] 
23. de Gallitzin, D. Lettre a Monsieur le Conseiller et Professeur de Crell ou Observations sur le Catalogue Methodique et Raisonné de la Collection de Fossiles de Mlle E. De Raab, par Mr. de Born; NiedersächsischeStaats-undUniversitätsbibliothek: Brunswick, Germany, 1797. (In French)

24. de Gallitzin, D. Seconde Lettre a Monsieur de Crell, ou Réflexions sur la Minéralogie Moderne; NiedersächsischeStaats-undUniversitätsbibliothek: Brunswick, Germany, 1799. (In French)

25. Klaproth, M.H. Chemische Untersuchung des rothen Granats aus Grönland. In Beiträge zur chemischen Kenntniss der Mineralkörper; Heinrich August Rothmann: Berlin, Germany, 1810; Volume 5. (In German)

26. Hausmann, J.F.L. Handbuch der Mineralogie; Vandenhoeck und Ruprecht: Göttingen, Germany, 1813; Volume 2. (In German)

27. John, J.F. Chemische Untersuchungen mineralischer, vegetabilischer und animalischer Substanzen - Fortsetzung des chemischen Laboratoriums; Friedrich Mauren: Berlin, Germany, 1810. (In German)

28. Pfaff, C.H. Ueber die Mischung der granatartigen Fossilien, den grönländischen schaaligen Pyrop, ein neues titanhaltiges granatartiges Fossil aus Arendahl (Rutilit), den sogenannten Zirkongranat, und die Aehnlichkeit der Zirkonerde mit dem Titanoxyd. J. für Chem. Phys. 1817, 21, 233-253. (In German)

29. Ussing, N.V. Geology of the country around Julianehaab, Greenland. Medd. om Grønland 1912, 38, 1-426.

30. Ryan, A.N. The Causes of the British Attack upon Copenhagen in 1807. Engl. Hist. Rev. 1953, 68, 37-55. [CrossRef]

31. Allan, T. Memorandums respecting some Minerals from Greenland. Ann. Philos. 1813, 1, 99-110.

32. Allan, T. XI. Remarks on a mineral from Greenland supposed to be crystallised gadolinite. Earth Environ. Sci. Trans. R. Soc. Edinb. 1812, 6, 345-351. [CrossRef]

33. Farrar, W.V.; Farrar, K.R. Thomas Allan, mineralogist: An autobiographical fragment. Ann. Sci. 1968, 24, 115-120. [CrossRef]

34. 1808 pounds in 2017|UK Inflation Calculator. U.S. Official Inflation Data, Alioth Finance. Available online: https://www.officialdata.org/1808-GBP-in-2017 (accessed on 24 June 2019).

35. Thomson, T. Experiments on Allanite, a new Mineral from Greenland. J. Nat. Philos. Chem. Arts 1811, 29, 47-59. [CrossRef]

36. Thomson, T. A Chemical Analysis of Sodalite, a new Mineral from Greenland. J. Nat. Philos. Chem. Arts 1811, 29, 285-292. [CrossRef]

37. Pfaff, C.H. Analyse eines neuen aus Grönland von Herrn Professor Giesecke mitgebrachten Granatartigen von Herrn Prof. Stromeyer Eudyalith genannten Fossils, und Auffindung einer neuen Substanz in demselben. Journal für Chemie und Physik 1820, 29, pp-1. (In German)

38. Pfaff, C.H. 1820. Correspondenz. Aus einem Briefe des Hrn. Prof. Pfaff in Kiel. Journal für Chemie und Physik 1820, 29.

39. Stromeyer, F. Untersuchung des Eudialyts von Kangerdluarsuk in Grönland. In Untersuchungen über die Mischung der Mineralkörper und anderer damit verwandten Substanzen; Vandenhoeck und Ruprecht: Göttingen, Germany, 1821; Volume 1. (In German)

40. Weiss, C.S., XXII. Ueber das Krystallsystem des Eudialytes. Verhandlungen der Gesellschaft naturforschender Freunde zu Berlin 1829, 1.

41. Rammelsberg, C.F. Handwörterbuch des chemischen Theils der Mineralogie, Erste Abstheilung A-M.; Verlag von C. G. Lüderitz: Berlin, Germany, 1841. (In German)

42. Friedrich, C. (Institut für Geschichte der Pharmazie, Marburg, Germany). Personal communication, 15 February 2018.

43. Bley, L.F.; Hofraths, D.L.d.G.; Barth, J. Trommsdorff in besonderer Rücksicht auf seine Leistungen für Chemie und Pharmacie. Den älteren Chemikern und Pharmaceuten zur Erinnerung der Verdienste des Verewigten, den jüngeren zur Nacheiferung aufgestellt. Arch. der Pharm. 1839, 18, 113-145. (In German) [CrossRef]

44. Klaproth, M.H. Chemische Untersuchung des Leucits. In Beiträge zur chemischen Kenntniss der Mineralkörper; Heinrich August Rothmann: Berlin, Germany, 1797; Volume 2. (In German)

45. Vauquelin, N.-L. Analyse de l'Aigue marine, ou Béril; et découverte d'une terre nouvelle dans cette pierre. Ann. de Chim. 1798, 26, pp-155. (In French)

46. Trommsdorff, J.B. Chemische Untersuchung des sächsischen sogenannten Berylls und Entdeckung einer neuen einfachen Erde in demselben, welcher man de Namen Agusterde ertheilt hat. J. der Pharm. für Ärzte Apoth. und Chem. 1800, 8, 138-152. (In German) 
47. Vauquelin, N.-L. Note sur la pierre appellee beril de Saxe. J. de Phys., de Chim., d'Histoire Nat. et des Arts 1803, 57, 329. (In French)

48. Giesecke, C.L. A Descriptive Catalogue of a new Collection of Minerals in the Museum of the Royal Dublin Society to which is added an Irish Mineralogy; R. Graisberry: Dublin, Ireland, 1832; pp. 1-268.

(C) 2019 by the author. Licensee MDPI, Basel, Switzerland. This article is an open access article distributed under the terms and conditions of the Creative Commons Attribution (CC BY) license (http://creativecommons.org/licenses/by/4.0/). 